\title{
THE USE OF WHATSAPP AS A PRACTICE TOOL IN A VIRTUAL COMMUNITY IN AN EARLY CHILDHOOD AND ELEMENTARY SCHOOL EDUCATION
}

USO DO WHATSAPP COMO INSTRUMENTO DE PRÁTICA DE UMA COMUNIDADE VIRTUAL EM UMA ESCOLA DE EDUCAÇÃO INFANTIL E EDUCAÇÃO FUNDAMENTAL

\section{LA UTILIZACIÓN DEL WHATSAPP COMO HERRAMIENTA DE UNA COMUNIDAD DE PRÁCTICA VIRTUAL EN UNA ESCUELA DE EDUCACIÓN INFANTIL Y ENSEÑANZA FUNDAMENTAL}

Nelson Tenório ${ }^{1}$; Rejane Sartori ${ }^{2}$; Cristiane Resquiti Paulino Strozzi ${ }^{3}$; Gabriel Coutinho Calvi ${ }^{4}$; Andréia de Cássia Goncalves Costa ${ }^{5}$

\begin{abstract}
A community of practice (COP) is based on the interaction among its participants, encouraging them to participate in permanent dialogue to disseminate and share knowledge. In this context, the research aimed to analyze the organizational culture sharing by creating and using a virtual CoP in a private pre-elementary and elementary school that used the WhatsApp application. It is a case study of qualitative nature as it analyzed the individual's participation in the CoP. In addition, a questionnaire was applied to verify whether knowledge sharing was practiced within the CoP. The results show that information sharing was productively managed through elements, participation, and commitment from the group of people participating in the CoP.
\end{abstract}

KEYWORDS: Communities. Technology. Educational management.

\footnotetext{
${ }^{1}$ Doutor em Ciência da Computação - Pontifícia Universidade Católica do Rio Grande do Sul. Porto Alegre, RS Brasil. Pós-doutorado - IT University de Copenhague, Dinamarca. Docente permanente - Programa de PósGraduação em Gestão do Conhecimento - UniCesumar. Maringá, PR - Brasil.

Email: nelson.tenoriojr@gmail.com / nelson.tenorio@unicesumar.edu.br

2 Doutora em Engenharia e Gestão do Conhecimento - Universidade Federal de Santa Catarina (UFSC).

Florianópolis, SC - Brasil. Assessora da Reitoria - Universidade Estadual de Maringá (UEM). Maringá, PR - Brasil. Docente do Programa de Pós-Graduação Stricto Sensu em Gestão do Conhecimento - UniCesumar. Maringá, PR - Brasil. Email: rejanestr@gmail.com / rejane.sartori@unnicesumar.edu.br

${ }^{3}$ Mestre em Gestão do Conhecimento nas Organizações. Mantenedora da Escola Criarte - Educação Infantil e Ensino Fundamental e sócia da Instituição de Ensino Médio Colégio Axia. Maringá, PR - Brasil.

Email: criarte@escolacriarte.com.br

${ }^{4}$ Mestre em Gestão do Conhecimento nas Organizações - Centro de Ensino Superior de Maringá. Maringá, PR Brasil. Tutor do ensino a distância do Centro de Ensino Superior de Maringá. Maringá, PR - Brasil.

Email: biecalvi@gmail.com

${ }^{5}$ Mestranda em Gestão do Conhecimento nas Organizações - Centro Universitário de Maringá - Unicesumar. Maringá, PR - Brasil. Coordenadora de curso- Formação de Docentes - Colégio Estadual Paiçandu.

Email: andreiacassiacosta@gmail.com
}

Submetido em: 22/03/2020 - Aceito em: 20/02/2021

(C) ETD- Educação Temática Digital Campinas, SP v.23 n.4 p.1002-1021 out./dez. 2021 


\section{RESUMO}

A comunidade de prática (CoP) baseia-se na interação entre seus participantes, incentivando-os a participar de um diálogo permanente, compartilhando e disseminando conhecimento. Nesse contexto, a pesquisa teve como intuito analisar o compartilhamento da cultura organizacional, criando e aplicando o uso de uma CoP virtual no contexto de uma escola primária privada que utilizou o WhatsApp. Portanto, a metodologia utilizada é um estudo de caso, com objetivo qualitativo. Os métodos qualitativos apresentam uma análise dos sujeitos. Qualitativa porque oferece uma análise da participação dos sujeitos na CoP. Posteriormente, aplicou-se um questionário para verificar se o conhecimento dos participantes foi compartilhado na CoP. Os resultados demonstram que o compartilhamento de informações foi gerenciado de forma produtiva através do domínio dos sujeitos, participação e comprometimento dos sujeitos envolvidos.

PALAVRAS-CHAVE: Comunidade. Consumo de Tecnologia. Administração da Educação.

\section{RESUMEN}

La Comunidad de Práctica (CoP) se basa en la interacción entre sus participantes. Esto sirve como incentivo para la participación en un diálogo permanente para la diseminación y el intercambio de conocimientos. En este sentido, esta investigación tiene como objetivo analizar el intercambio de conocimientos dentro de la organización, a través de la creación y la implementación de una CoP virtual, en una escuela privada de educación infantil y educación básica, con el uso de la aplicación Whatsapp. Por lo tanto, es usada una metodología que estudia cada caso, planteando objetivo cualitativo. Los objetivos cualitativos se plantean a partir de un análisis de la participación de los miembros de la CoP. Posterior a la participación de los miembros de la CoP, se realiza un cuestionario con el fin de verificar si realmente se compartieron conocimientos por medio del intercambio de experiencias y saberes. Los resultados revelan que tal intercambio de informaciones fue realizado productivamente al demostrar dominio de los contenidos, participación y compromiso de parte de los miembros participantes de la CoP.

PALAVRAS-CLAVE: Comunidad. Consumo de tecnología. Administración de la educación.

$* * *$

\section{INTRODUCTION}

The role of the school transcends the pure content linear transmission to constitute liberating education, aiming at a formation for life, leading the individuals to constitute the principles of citizenship and ethics to become active in society (NUNES; SILVEIRA, 2009). Thus, the school environment should encompass collective learning, in which teachers and students can contribute directly to the socio-cultural development from the creation and sharing of built knowledge (SENGE et al., 2005).

Considering the schools as places of knowledge creation and development, school agents share knowledge to collaborate so that learning occurs with no difficulties. Among the challenges found in the school environment related to this sharing is the incomprehension of organizational processes, inflexible procedures, lack of operational routine reviews, manual of immutable methods, mental models, histories, and beliefs that permeate the culture of organizations (TONET; PAZ, 2006; DEJA, 2019). Therefore, people sharing experiences within a group is one of the most common practices for sharing knowledge (NONAKA; TAKEUCHI, 2008). 
Among the resources used by organizations to share experiences in groups, the Communities of Practice (CoP) stands out. A CoP can be defined as a group of people who get together to share knowledge and enhance their learning through their shared resources and dynamic resources (DALKIR, 2017). In this perspective, CoPs offer a solution to facilitate the promotion and formation of knowledge construction, imposed by geographical barriers, in this case, through technology. In this sense, Wiig (2002) states that, in an organizational context, knowledge sharing is a pre-condition and is vital to transform information or isolated experiences into something the whole organization can use. Thus, with the use of technologies, CoPs becomes outstanding cooperative environments that enable dynamic and flexible interactions among its participants.

Advances and access to new technologies provide for CoP reorganization as technologies offer communication channels for people to share their knowledge. Thus, the basis of CoPs becomes Computer-Supported Cooperative Work (CSCW). For instance, techcommunication tools, the so-called chat-tech, are intensively adopted in the workplace as applications such as WhatsApp, Telegram, and Skype are being used to coordinate work, scheduling, and discussion and interaction groups (TENÓRIO; BJØRN, 2019a; TENÓRIO; PINTO; BJØRN, 2017; PINTO; GARCIA; TENÓRIO, 2017; HANDEL; HERBSLEB, 2002). Thus, previous CSCW research explores the work supported by technologies (BJØRN; HERTZUM, 2011) by fragmenting the nature of the still fundamentally important invisible work performed by secretaries, nurses, and remote workers, and others (BOSSEN, FOSS, 2016; WAGNER, 1993). Despite the issues raised by chat-tech, for instance, moral or sexual harassment - even within workgroups (TENÓRIO; BJØRN, 2019b), technology, when well used, is the central drive for information and knowledge sharing in both personal and organizational spheres, in addition to allow the formation of communities with no geographical boundaries. The product of this relationship involves a triad of tech-oriented workgroups through teaching, cooperation, and technology.

In this sense, this article aims to analyze the knowledge sharing process organized through the creation and use of a CoP in the WhatsApp to discuss the learning factors achieved in the process of pedagogical training of a private elementary school. This article is organized in six sections, with section 2 addressing the relationship between Knowledge Management and Education; section 3 presents the concept of CoPs and their relation with technology; section 4 presents the methodology used to carry out this research; section 5 presents and discusses the obtained results, and section 6 presents our conclusions. 


\section{KNOWLEDGE MANAGEMENT WITHIN EDUCATION}

Knowledge is the fundamental factor behind an organization success. The origin of knowledge lies in information, i.e., a set of relevant data in the constitution of its meaning. While data and information can be stored in computers, knowledge cannot, as it is qualified as personal and faces challenges to be transferred. Davenport and Prusak (1998) argue that information only becomes knowledge when people perform their tasks, whether working, studying, or accomplishing other different activities.

Knowledge Management instrumentalizes the creation, transfer, and application of knowledge to guarantee its sustainability and innovation, pursuing the organization's goals. Hence, Knowledge Management is found in management, education, and library (BATISTA, 2015; CHENG; LEE, 2016; DALKIR, 2017). Therefore, Knowledge Management occupies a prominent position in organizations for providing tools to allow human capital (CHOO, 2006).

Human capital involves individuals' education, skills, and background, necessary to be productive in an organization (DALKIR, 2017). In this sense, the school is an environment capable of transforming information into knowledge and brings human capital to the individuals. However, information is not always systematized in considering administrative actions. Thus, school management provide the set of rules, guidelines, and organizational structure that ensures material, financial, and intellectual resources (LIBÂNEO, 2007; 2009). School management aims to coordinate and accompany people's work providing the optimal functioning of the school and activities in the classroom, ensuring better learning opportunities for all students.

Given this scenario, Knowledge Management provides the schools with the capacity to optimize time, space, and resources, establishing a different culture of knowledge acquisition and sharing, extracted from the human capital contained in the institution's staff, aiming to improve the quality and efficiency of the school as a whole (DEJA, 2019; LLARENA; DUARTE; SANTOS, 2015). Thus, knowledge can be used to improve school competitive performance; however, such knowledge must be systematically created, organized, updated, and disseminated in the institution (CHENG; LEE, 2016; SENGE; MACCABE; LUCAS, 2005; SAEED; KAVEH; VAHID, 2020).

In this way, Knowledge Management in schools establishes an organizational knowledge system in which new necessities and requirements arise due to continually changing and evolving conditions (KAYA; 2020). It allows teachers and principals to create new policies and practices to improve learning and strengthen people's professional competencies (DONMOYER, 2020). Furthermore, it enhances the structure and politics of the organization. Thus, Knowledge Management can help improve schools as it favors the creation, sharing, and application of people's knowledge, increasing their pedagogical and 
organizational competence. Therefore, the educational organizations' main task is to create a knowledge culture in schools and ensure widespread knowledge.

\subsection{Communities of Practices and Knowledge}

A CoP is a structure that can sustain and develop pedagogical competence in schools, it is part of a broad spectrum when thinking about learning in its social dimensions as learning is not inside or outside people's heads, but rather in the relationship they establish with the world (WENGER, 2010). Table 1 shows some systematized concepts of CoP.

Table 1. Concepts of CoP

\begin{tabular}{|c|c|}
\hline Author & Concept \\
\hline $\begin{array}{c}\text { APO } \\
(2020)\end{array}$ & $\begin{array}{l}\text { Made up of groups of people, either face-to-face (and) or virtually, who share their } \\
\text { knowledge about a specific topic they already practice, but who seek to improve it further. } \\
\text { They can be formed spontaneously or intentionally to share what they know and create new } \\
\text { skills. }\end{array}$ \\
\hline $\begin{array}{c}\text { Gnecco et al. } \\
\text { (2012) }\end{array}$ & $\begin{array}{l}\text { Can be understood as a network of individuals with common interests (and problems) who } \\
\text { come together to identify solutions, share practices, ideas, exploring forms of collaborative } \\
\text { work. }\end{array}$ \\
\hline $\begin{array}{c}\text { Noro et al. } \\
(2016)\end{array}$ & $\begin{array}{l}\text { It is organized based on tools that help to create knowledge and provide the necessary } \\
\text { conditions for interaction between individuals within the community and among other } \\
\text { places. }\end{array}$ \\
\hline $\begin{array}{c}\text { Fogaça e Halu } \\
\text { (2017) }\end{array}$ & $\begin{array}{l}\text { CoP's work is based on collaboration. This work will depend on a desire for consensus, crucial } \\
\text { to its emergence and maintenance - a willingness to share values, build collective visions, } \\
\text { and set goals that are achieved through working together. }\end{array}$ \\
\hline
\end{tabular}

Source: The authors (2020).

The use of CoP enables and facilitates information and knowledge exchange among its participants, as it allows the improvement of its practices, expanding knowledge efficiently and effectively (SARTORI, 2012). In this sense, a CoP provides the connection of people, encouraging the development and sharing of ideas, strategies, and knowledge. Also, it enables rapid problem resolutions, minimizes rework, reduces geographical limitations, and offers a variety of options for collaborative work, reflection and self-development, and discussion of everyday issues. Therefore, a CoP is based on collaboration and, especially, on the participants' desire to share values, produce broad visions and set goals that will be achieved through collective work (FOGAÇA; HALU, 2017). 
Gnecco et al. (2012) report that we need to consider what we want to achieve with CoPs. It is also necessary to reflect on the level of participants' contribution in these communities, their roles, and specialists' and facilitators' responsibilities, and how to provoke the interest and the engagement of the group to promote knowledge creation and sharing, adding progress and evolution to the discussions. Noro et al. (2016) state that interaction and socialization of CoP participants favor learning in organizations, making them an important tool for Organizational Knowledge Management.

Although several activities can be carried out in a CoP, such as discussing a proposed topic, drafting a document, sharing content developed by some of the participants and disseminating it to others, a Cop's lifetime is often limited. This limitation is because after achieving the proposed goal, it may decrease the individuals' interest and participation. However, this cannot be considered as a negative point as when the CoP lifetime is short may be because it has achieved the proposed goal or the expected result. Conversely, CoP's lifetime may be extended because of the type of relationship, and learning the group has offered (WENGER, 2004). Therefore, the synergy between time, dedication and involvement based on trust is the main element for a community to develop (SARTORI, 2012). The CoP development stages depend on the levels of participants' interaction and on the activities each participant performs (WENGER, 1998). Table 2 presents the CoP stages and their actions.

Table 2. CoP Stages

\begin{tabular}{|c|c|}
\hline Stage & Action \\
\hline Potential & $\begin{array}{l}\text { Individuals are at the same level and do not share information in the community for various } \\
\text { factors related to motivation. }\end{array}$ \\
\hline Coalesce & The group members recognize their potential. \\
\hline Dispersed & $\begin{array}{l}\text { Members are no longer engaged in the discussions, but the community still exists as a center } \\
\text { of knowledge sharing. }\end{array}$ \\
\hline Memorable & $\begin{array}{l}\text { The CoP is no longer the center of discussions, but people are reminded of it collecting } \\
\text { memories. }\end{array}$ \\
\hline
\end{tabular}

Source: Adapted from Wenger (2008).

All of the CoP stages allow understanding the attitude of the members that integrate it and enables to raise hypotheses regarding the motivations and barriers when sharing knowledge within the community. As motivations for sharing, Ipê (2003) highlights knowledge as power, in which an individual who shares stands out from the others and gains value from the organization. Reciprocity, because people share knowledge with each other, therefore acquiring more knowledge, and the reward for sharing, which is linked to financial and status benefits within organizations, among others.

(C) ETD- Educação Temática Digital Campinas, SP v.23 n.4 p.1002-1021 out./dez. 2021 
As barriers to sharing, Disterer (2001) presents factors such as the loss of power, because when sharing knowledge the individual loses the exclusivity of specific knowledge. There may be uncertainty that the knowledge an individual possesses is essential to the company and yet the generation of fears and constraints since negative feelings can be continuously arisen in other people who compose the organization.

Dalkir (2017) states that some community members play an active role in contributing to the discussions, but there are also some who read the publications without taking an active part in them. For the author, these people are the lurkers, term that can be translated by legitimate peripheral participation. But it is a fact, according to the author, that the higher the involvement of the members, the greater the benefits the CoP will obtain, with people who post comments and have active participation in the community are generally around $10 \%$, while $90 \%$ of the members visit community regularly, but do not post anything.

Therefore, the assumptions guiding the CoP, according to Plessis (2008), refer to learning as a social phenomenon and, therefore, people organize themselves in communities where they are already inserted. In the school environment, the role of a CoP coincides to the school's role as it becomes a robust learning environment as knowledge is integrated into the life of the community (WENGER, 2010). Thus, a CoP must be experienced by all teachers who belong to this context and compose meaningful learning relationships that value pedagogical work. Thus, a CoP in a school environment promotes the association of teachers with the purpose of sharing, exchanging ideas and reflections to develop a search for virtual environments that contribute to improving pedagogical practices.

\subsection{Communities of Practice and Technology}

Technology as a tool is increasingly present in the school routine, in the elaboration and presentation of classes, for instance, and appears as a prime factor to promote learning sharing through a CoP. Technology-related tools facilitate information contextualization, social interactions and networking, as direct communication and the transfer of verbal knowledge through social interactions among people is the most natural aspect of knowledge sharing (GHANI, 2009).

With the advent of technology, CoPs undergo a reconfiguration and adopt virtual environments as a channel for communication among people (FLINT, 2013; WENGER, 1998). Existing geographic barriers are not as relevant as before, as tools such as e-mail, Short Message Service (SMS) and applications, e.g., WhatsApp, come into play to ensure that communication happens as best as possible. Therefore, the alliance between people and technologies enables the progress in organizations to take place thanks to the systematization of the existing communication processes. Although the concept of CoP implies the support of technologies nowadays, some authors also consider the idea of 'virtual CoP,' where CoP has 
a social grouping in cyberspace connected by information and communication networks aimed at a common goal (FLINT, 2013; SARTORI; ROESLER, 2003).

CoPs are the focus on modernity to ensure that the various subjects that make up organizations participate actively in the process of building organizational knowledge. In schools, knowledge is being gathered in spaces of individuals or collective interests (SANTOS, 2018). In this sense, the triad comprising people, technology, and learning can show positive results if the CoP is articulated with technological applications such as Skype or WhatsApp (PINTO; GARCIA; TENÓRIO, 2017; RATAN; DIVYA, 2019) or even email, blogs, face-to-face or virtual meetings, videoconferences, discussion forums (SANTOS, 2018). With the purpose of not only sharing knowledge, but also building knowledge among its members, CoPs allow the constitution of intellectual capital and internal capital in organizations.

All these tools cooperate with knowledge dissemination and construction within and outside the CoP boundaries. Thus, some crucial steps need to be followed for the CoP implementation. These steps include the relation between the person and organization so that both benefit from the practice of practices. In this sense, Vieira (2006) indicates that the process of CoP implementation and development by the organizations is carried out in nine steps. In the first step, the coordinator is assigned, which happens after the analysis of the subjects that compose the CoP. The coordinator will be responsible for mediating the shared information. In the second step, the identification of the informal networks takes place, and an analysis is made to prevent conflicts with the existing tools. The third step identifies among the people of the organization those who have the potential to participate in the practice the CoP aims to work. The fourth step brings together the participants and the groups that have the same purpose and, afterwards, the division of tasks is carried out. In the fifth step an analysis of the challenges and problems of the organization takes place, so a CoP is formed to solve a problem or to share the knowledge that only some of the members had access in formations, workshops, conferences, etc., equalizing this learned knowledge. In the sixth step, the CoP must provide infrastructure for the development of the activity, i.e., the training some members received is shared with others. In the seventh step, the members who shared their knowledge receive a reward from the CoP. The eighth step turns to the measurement of what everyone has learned from the practice developed by the CoP to disseminate its results. Finally, the ninth step discloses the CoP results and takes stock of the performed activities. Figure 1 presents the process of each of the stages of CoP development and deployment.

(C) ETD-Educação Temática Digital Campinas, SP v.23 n.4 p.1002-1021 out./dez. 2021 

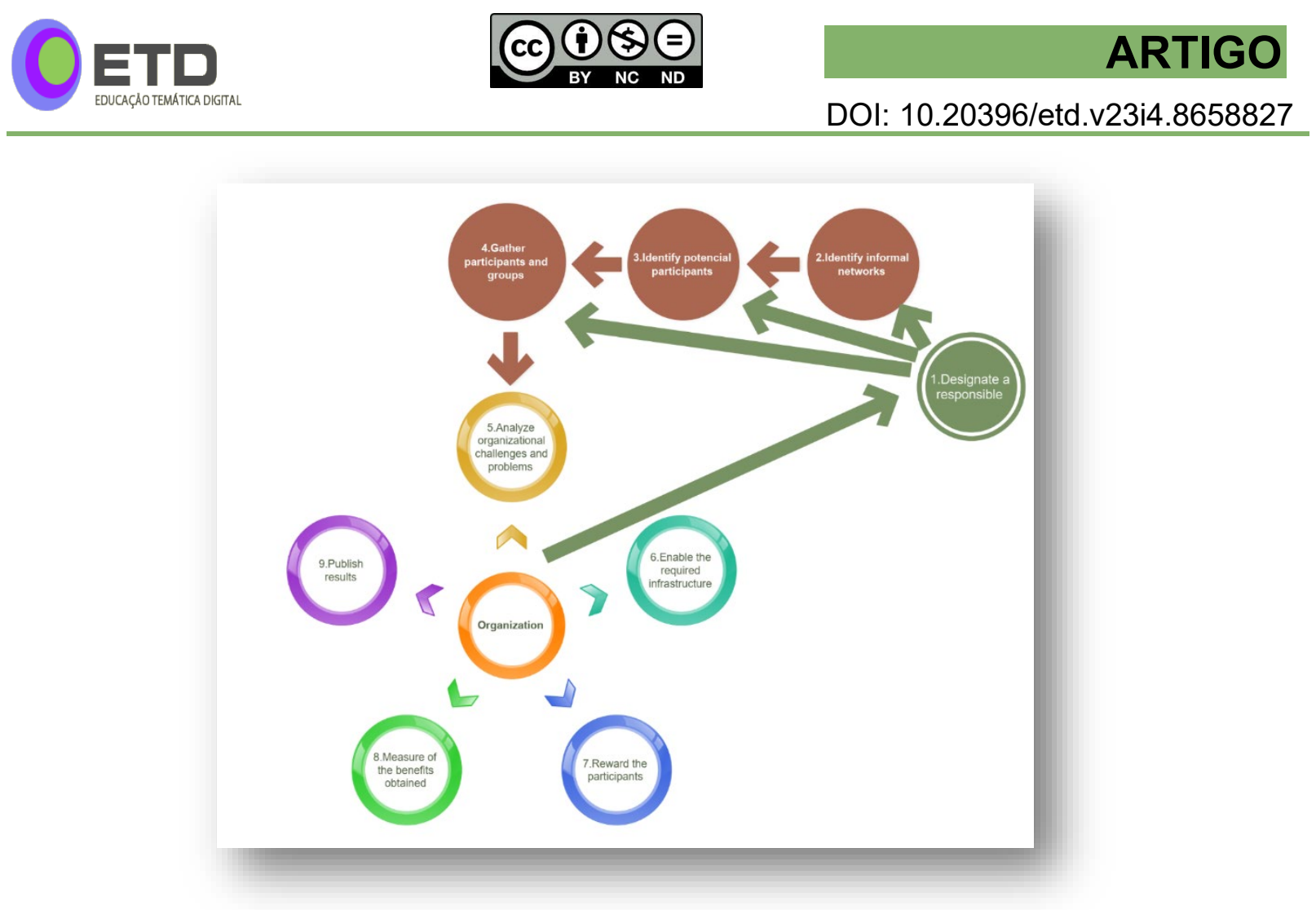

Figure 1: CoP Adaptation in the organization Source: Adapted from Vieira (2006, p. 10).

All the steps for the CoP implementation can present effective results if, in choosing the tool, the one that best suits the reality of the organization is selected, also considering the technical abilities of the individuals so that everyone can explore the environment created in the best way possible. Cambraia (2012) points out that it is crucial to be careful not to use too sophisticated or too obsolete technologies to avoid community members evasion - and perhaps for its simplicity, messaging applications are gaining so much popularity to articulate the CoPs. Therefore, the idea is to consider the subjects' profiles and their technological knowledge before defining which tool to be used to support a CoP within the organization. 


\section{METHODOLOGY}

To investigate knowledge sharing using a WhatsApp group, a qualitative case study was conducted, as suggested by Yin (2010). The created CoP was called 'Practical Community Forming'. The object of study of this research is a private school, in southern Brazil, which began its activities in 1988 with early childhood education and, in 2002, introduced elementary education. The school has 356 students and seventy-three employees. The research subjects were elementary school 1 teachers (from 1 st to $5^{\text {th }}$ grades) and elementary school 2 teachers (from $6^{\text {th }}$ to $9^{\text {th }}$ grades), totalizing forty-four teachers who work directly with the school's pedagogical sector. The other nineteen employees did not participate in the investigation as they did not work as teachers.

\subsection{Empirical Settings}

We decided to create a WhatsApp CoP after thirteen teachers participated in a conference. We choose the WhatsApp tool as the teachers use it to communicate with each other about different subjects. For instance, news, warnings, timetables, classes and students' performance and issues, in addition to jokes and supporting messages. The CoP was addressed to disseminate the conference knowledge with forty-four invited teachers who did not attend the event. We explained the participants the CoP's goals at the time of its creation. The conference, which took place between March and April, 2018 in the southeast region of Brazil, was aimed at continuing education for teachers, coordinators, and school managers. Of the forty-four invited teachers, only thirteen accepted to participate in the CoP: four 'course coordinators,' four early childhood education teachers, two 'elementary school 1 ' teachers, and three 'elementary school 2' teachers. At WhatsApp CoP, teachers who attended the conference were asked to share and disseminate the knowledge they received during the conference. The conference topics were related to literacy, executive functions, educational material, and interdisciplinarity. After the event and the CoP creation, we elaborated and sent all teachers' schools a questionnaire containing five-multiple-choice questions to measure whether or not the topics discussed in the CoP had been relevant to them. Each question had only one correct answer, contemplating what was mentioned the CoP. The percentage of correct answers indicated the level of interaction and knowledge acquisition from the CoP members. Even though only thirteen teachers agreed to attend the CoP, the questionnaire was submitted and answered by fifty-four teachers. The participants, six men and forty-nine women aged between eighteen and fifty-one years old, had higher education degrees.

\subsection{Data Collection}

After the thirteen teachers returned from the conference, we invited them to participate in a WhatsApp CoP. We instructed them to write out a script of the topics to be discussed based on the conference's themes to be posted in the WhatsApp CoP as a way of disseminating the knowledge they acquired. Initially, we started the CoP in a WhatsApp

(c) ETD-Educação Temática Digital Campinas, SP $\quad$ v.23 $\quad$ n.4 $\quad$ p.1002-1021 out./dez. 2021 
school manager's existing group to avoid 'new groups.' Due to the low participation and the mixed subjects (e.g., management subjects, news, reports, notices, and warnings), we decided split the CoPs into three different WhatsApp groups by education level, i.e.,' early childhood education', 'elementary school 1', and 'elementary school 2,' and include the teachers and coordinators according to each level. From the beginning of the chats, on May 6,2018 , we observed all groups daily for 32 days. We registered the number of messages exchanged during our observations, the discussed subjects, and these topics' frequencies and recorded them into a spreadsheet. We observed a total of 376 message exchanges by the participants in the three CoPs. We also observed the teachers' increased participation in the conference and the CoP leaders, managers who attended the conference and engaged in instigating and encouraging the CoP discussions. Immediately after the closure of the CoP, 32 nd day, we conducted a questionnaire addressed to evaluate the understanding of the discussions by the attendees once they brought questions related to the discussed topics. In addition, we also conducted a self-assessment of the type of CoP's attendees, for instance, whether they participated actively - reading and posting or only reading or even not reading, and whether or not the CoP discussions were consistent with the conference topics.

\subsection{Data Analysis}

We analyzed data observing all the three WhatsApp CoP groups for 32 days. Firstly, we exported all messages from WhatsApp CoP to text files in format '.csv' and opened them in spreadsheets. Next, we read and classified those messages running a thematic analysis (CRESWELL; POTH, 2018; SALDAÑA, 2015; MILES; HUBERMAN; SALDAÑA, 2014). Moreover, based on the conference's topics - i.e., interdisciplinarity, courseware usage, executive functions, and literacy. So, we calculated the subjects' frequency. Secondly, we analyzed the self-assessment through the percentual of participants, i.e., how many participants answered the self-assessment questionnaire and the self-assessment score for those who answered it. Both percentages and scores were calculated through spreadsheets.

\section{RESULTS AND DISCUSSION}

Due to the emergence of Knowledge Management within Education - section 2, and the CoPs supporting pedagogical competences, different work groups are created in chattech, especially in apps such as WhatsApp, Facebook Messenger, and Telegram. These workgroups are addressed to promptly support communication by registering people's chats (TENÓRIO; BJØRN, 2019a, TENÓRIO; PINTO; BJØRN, 2017; PINTO; GARCIA; TENÓRIO, 2017). Although harassment issues raised by chat-tech are a drawback (TENÓRIO; BJØRN, 2019b), chat-techs represent an opportunity to organize and take tech-advantages to create workgroups which are present in personal or corporative portable devices. A CoP is crucial for the school's community to produce knowledge, discussing and sharing different experiences among its participants. Thus, it is essential for school teachers and managers to integrate the 
notion of CoPs to understand the process of knowledge sharing into chat-tech, particularly apps, to create, organize, and manage well the CoP running over the apps. Therefore, to use a tech-chat effectively to support a CoP, in particular WhatsApp, our research revealed: firstly, a CoP should not arise whether created over an existing group, so we suggest 'do not reuse existing groups'; secondly, it is important to 'establish a tech-savvy leader' - not necessarily an expert in technologies. The tech-savvy leader's role is to build the CoP in a chattech and support its participants regarding tech-issues such as sending files and media files, recording voice, finding and downloading files on a computer or other devices. Finally, we discuss our results in details as follows.

Do not reuse existing groups. Initially, a first attempt was made to open a CoP in a current WhatsApp group. However, this did not work as when reusing a group, other subjects emerge, such as disciplinaries, students, and parents' issues, lists of purchases, letters from the academic secretariat, among other topics. Therefore, the discussion was dispersed, and we did not observe any conference topics. So, reusing an existing group did not have any effect on the discussion of the teachers' learning in the conference, it was reflected and concluded that it would be necessary to create three private groups for the discussions and directions interested in these subjects. Thus, the groups designed were: CoP Childhood Education, CoP Elementary 1 and CoP Elementary 2, to provide knowledge sharing among the topics of Early Childhood Education, Elementary School 1 and Elementary 2. After this procedure, the invitation was resent to the teachers, now separated by actions, obtaining more success both in the participants' adhesion and in their contributions for the CoP. As Sartori (2012) reports, a systematic process is needed to share and use knowledge to achieve the proposed objectives. Therefore, there is a need for rigor and criteria in creating a CoP as if it fails in this aspect, the CoP can be regarded as only another chat group (NORO et al., 2016).

Establish a tech-savvy CoP leader. We observed that each course coordinator (e.g., Early Childhood Education, Elementary 1 and Elementary 2) who attended the Conference assumed his/her role as a leader in the CoP to foster and broaden the discussions. Each coordinator gave a different approach according to the area he or she works in the school, i.e., educational or management. The Early Childhood Education CoP presented 205 messages, characterized as the group with more discussions. In this sense, the coordinator was a decisive factor in the action, as he/she possesses high technological abilities.

Considering the self-assessment, the results pointed out that $38 \%$ of the CoP attendees only read the CoP posts, while $44 \%$ participated as readers and posters. Moreover, $9 \%$ of the attendees did not fill out the self-assessment, and other $9 \%$ did not participate of the CoP, as shown in Figure 1.

(C) ETD- Educação Temática Digital Campinas, SP $\quad$ v.23 $\quad$ n.4 $\quad$ p.1002-1021 out./dez. 2021 


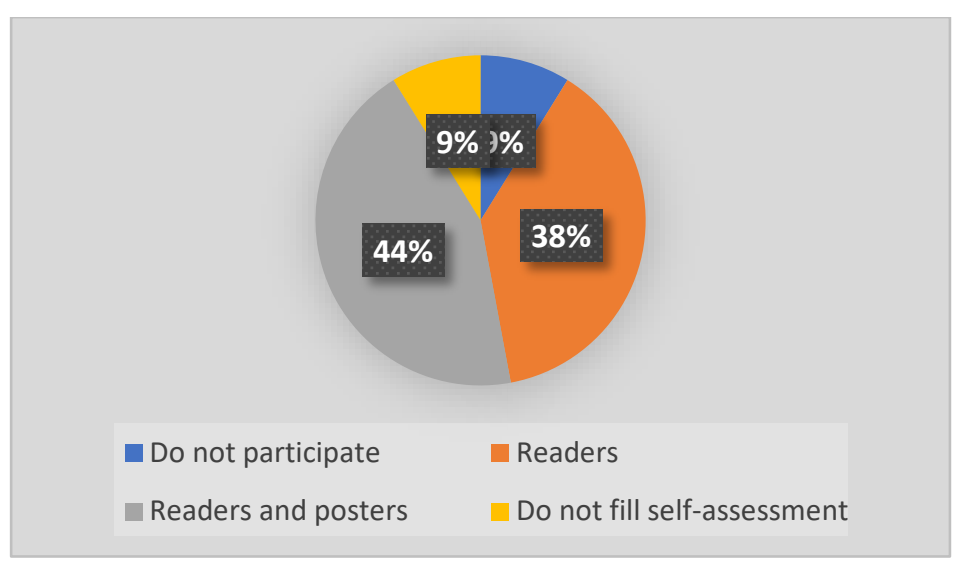

Graph 1. Percentage of CoP's attendee type Source: The authors (2020).

The self-assessment results showed that the CoP participants answered more than $90 \%$ correctly regarding literacy, executive functions, and interdisciplinarity. It demonstrates that the CoP accomplish its function to share knowledge among the teachers who did not attend the congress. Moreover, through the WhatsApp CoP they assimilated the conference's topics even not taking part of it. Regarding the questions based on the courseware usage (course material), the group was $75 \%$ accurate, demonstrating that some teachers did not use the material and responding incorrectly the questions, shown in Figure 2. It is noteworthy that most of the participants preferred to interact with the group (or only read posts) instead of reading the physical material.

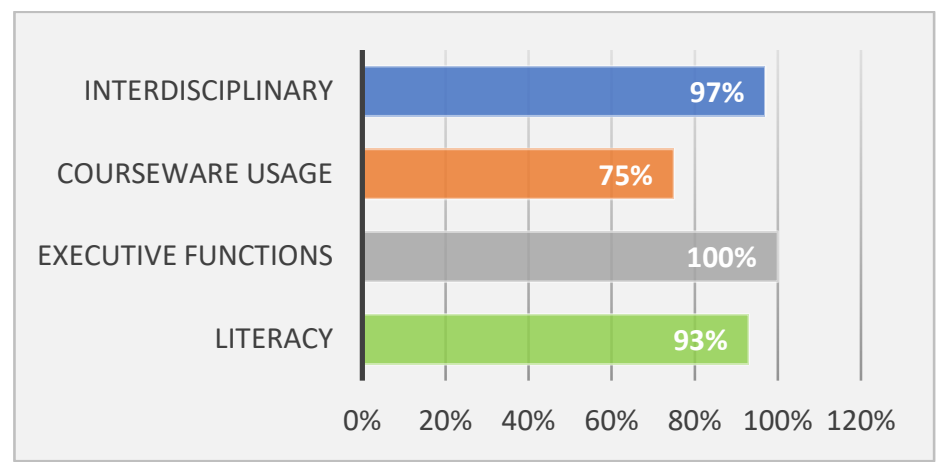

Graph 2. Percentage of correct questions

Source: The authors (2020).

It was clear that knowledge sharing in the WhatsApp CoP occurred effectively through the knowledge acquired and shared by the teachers who participated in the conference with those who did not attend it. Thus, the CoP stands out, because in the three presented themes, the perception of all the participants of the community was of mastering the content.

We observed that the messages in the CoP Childhood Education, Elementary 1 and Elementary 2 were more productive and had more involvement, as presented in Figure 3. Therefore, while the discussion on subjects related to the Conference in an already existing 
group was practically none, the use of specific groups, in this case, favored the increase of contributions and enriched discussions. It is, therefore, necessary to reflect on the usefulness of the CoP and its focus, the level of participants' contribution, the roles and responsibilities of the specialists and facilitators, and to arouse the group's interest and engagement in promoting knowledge creation and sharing.

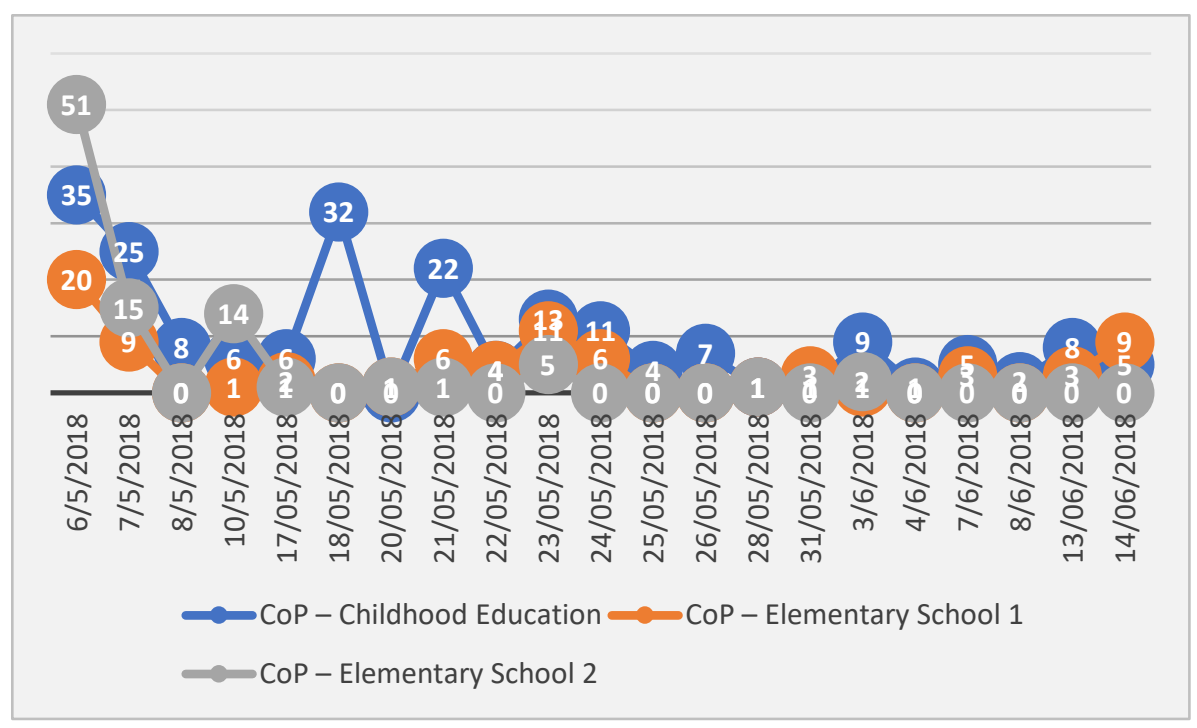

Graph 3. Number of chats in the CoP per day Source: The authors (2020).

At the CoP Elementary 1, there were 80 message exchanges. In this group the teachers were older and they also had little technological ability. In CoP Elementary School 2, the discussions were shorter, starting on the 06th until the 30th and there were 91 message exchanges. In these CoPs, the individuals were not only concerned with the themes of the Conference since they widely discussed other subjects.

Conversely, CoP Elementary 1 and CoP Elementary 2 did not have as many messages; for example, Elementary 1 totalized 80 messages, while in Elementary 291 messages were sent. These differences are because: at CoP Elementary 1, although the coordinator encouraged the discussions, participants were not familiar with dealing with the WhatsApp application. The CoP Elementary 2 was discussed for a shorter period of time, starting on 06th until 30th, 24 days total, and had 91 messages. It was also observed that in the three CoPs, the subjects often dealt with diverged discussions from the themes presented at the Conference, in this aspect we observed that the participants did not understand the real meaning of a CoP in dealing with specialized issues (WENGER, 2010, APO, 2020; GNECCO et al., 2012; NORO et al., 2016; FOGAÇA; HALU, 2017). Moreover, it is imperative that the CoP mediator keeps the group focused on the discussion. In this sense, the mediators act as specialists and facilitators to motivate participants' interest and engagement, promoting knowledge creation and sharing (GNECCO et al., 2012). 
The interaction provided by the CoPs, according to Noro et al. (2016), favors all participants' learning, highlighting the CoP as an essential tool, because the synergy in sharing knowledge, ideas, and experiences, further boosts the creation of new knowledge. However, this article shows that some care must be taken to ensure that a CoP, articulated through applications, is not implemented in existing groups. Also, it is critical to reflect and clarify the advantages of a CoP to the participants. Finally, it is necessary to carefully verify the experience of people with the technology adopted for the CoP - in this case; training can be developed, as well as defined mediators that promote and articulate the discussions according to the CoP's objective.

\section{CONCLUSION}

This research analyzed knowledge sharing through the creation and use of WhatsApp $\mathrm{CoP}$ in a private elementary school to discuss the lessons learned in an educational training meeting for teachers. From the obtained results, from the conduction of the questionnaires and the analysis of the CoP, we observed that knowledge sharing was managed productively, confirmed by the identification of the pillars that make up a CoP: the domain, the community, and the practice. The domain, related to the participants' interests, was measured by the correct answered indexes, demonstrating knowledge acquisition by the CoP members. It should be noted that the issues in the CoP discussions were focused on the topics debated at the Conference. Regarding the community, linked to the Group's sense of belonging, the research pointed out that, in addition to the network of contacts created through the CoP, a mutual help culture was developed among the participants, in which each participant knew how to give and receive help in the constant search to solve the possible problems by knowledge sharing. In the CoP practice, focused on sharing and collaborative work, shared tasks were established on a joint knowledge base. Therefore, the Conference material was assumed by the members to share the existing knowledge, causing the whole group to advance in the creation and application of new ideas. This interaction among the members and the knowledge documentation in the Group became part of their experience. Among the CoP's benefits were the creation of loyalty and commitment among members, a process of innovation in educational exercises due to the sharing of better practices and a significant improvement in process efficiency. The virtual CoP, after this pilot test, became part of the implementation of the Knowledge Management process of the school object of study, as other subjects were brought to the discussion, strengthening the tool. Therefore, it is reaffirmed that a CoP enables the connection of people, encouraging the development and sharing of ideas, strategies, and knowledge. This environment, after this research and the implementation of this Knowledge Management tool, will enable the teachers to solve problems quickly, minimize rework, and will also offer options for collaborative work, reflection and self-development of knowledge and discussions about issues.

(C) ETD- Educação Temática Digital Campinas, SP v.23 n.4 p.1002-1021 out./dez. 2021 


\section{REFERENCES}

ASIAN PRODUCTIVITY ORGANIZATION. Knowledge management tools and techniques manual. Tokyo: APO, 2020.

BATISTA, Fábio Ferreira. 0 desafio da GC nas áreas de administração e planejamento das Instituições Federais de Ensino Superior (IFES). Brasília, DF: Ipea, 2015.

BJØRN, Pernille; HERTZUM, Morten. Artefactual Multiplicity: A Study of EmergencyDepartment Whiteboards. The Journal of Computer Supported Cooperative Work (CSCW), v. 20, n. 1-2, p. 93-121, 27 Abr. 2011.

BOSSEN, Claus; FOSS, Martin. The Collaborative Work of Hospital Porters: Accountability, Visibility and Configurations of Work. In: ACM CONFERENCE ON COMPUTER-SUPPORTED COOPERATIVE WORK \& SOCIAL COMPUTING, San Francisco, California. Proceedings... New York, USA: ACM, 2016. p. 965-979.

CAMBRAIA, Adão Caron. Comunidades virtuais de prática: um espaço para formação permanente de professores. Revista Espaço Acadêmico, Maringá, v. 12, n. 139, p. 18-24, dez. 2012.

CHENG, Eric C. K.; LEE, John. C. K. Knowledge Management Process for Creating School Intellectual Capital. Asia-Pacific Education Researcher, v. 25, n. 4, p. 559-566, 2016.

CHOO, Chun Wei. A organização do conhecimento: como as organizações usam a informação para criar significado, construir conhecimento e tomar decisões. 2. ed. Tradução de Eliana Rocha. São Paulo: Senac, 2006.

CRESWELL, John W; POTH, Cheryl N. Qualitative inquiry and research design: choosing among five approaches. London: Sage, 2016.

DALKIR, Kimiz. Knowledge management in theory and practice. USA: MIT, 2017.

DAVENPORT, Tomas H.; PRUSAK, Laurence. Conhecimento empresarial. São Paulo: Campus, 1998.

DEJA, Marek. Information and knowledge management in higher education institutions: the Polish case. Online Information Review, v. 43, n. 7, p. 1209-1227, 11 Nov. 2019.

DISTERER, Georg. Individual and social barriers to knowledge transfer. In: HAWAll INTERNATIONAL CONFERENCE ON SYSTEM SCIENCES, 34, 2001, Hawaii, USA. Proceedings... Hawaii, USA, 2001. p. 1-7.

DONMOYER, Robert. Why is everything old new again? Revisiting debates about the form and function of research in educational administration. Journal of Educational Administration, v. 58, n. 3, p. 341-356, 31 Mar. 2020.

FLINT, R Warren. Practice of sustainable community development. New York, NY: Springer

(C) ETD-Educação Temática Digital Campinas, SP v.23 n.4 p.1002-1021 out./dez. 2021 
New York, 2013.

FOGAÇA, Francisco Carlos; HALU, Regina Célia. Comunidades de prática e construção identitárias de formadores em um programa de formação continuada. Revista RBLA, Belo Horizonte, v. 17, n.3, p. 427-454, 2017.

GHANI, Syed Raiyan. Knowledge Management: Tools and Techniques. DESIDOC Journal of Library \& Information Technology, v. 29, n. 6, p. 33-38, nov. 2009.

GNECCO, Lenio Júnior; SANTANA, Julival Queiroz; DALMAU, Marcos Baptista Lopez; SANTOS, Neri; RADOS, Gregório Jean Varvakis. Métodos e técnicas de GC: Comunidades de prática. Reuna, Belo Horizonte, v. 17, n. 2, p. 59-80, 2012.

HANDEL, Mark; HERBSLEB, James D. What is chta doin in the workplace? In: CONFERENCE ON COMPUTER-SUPPORTED COOPERATIVE WORK, 2002, New Orlens, LA, USA.

Proceedings..., New Orlens, LA, USA, 2002. p.1-10.

IPÊ, Minu. Knowledge sharing in organizations: A conceptual Framework. Human Resource Development Review, v.2, n. 4, Dec. 2003.

KAYA, Ayça. Knowledge Management for Education Administrators. In: Durnali, M.

(Org.). Utilizing technology, knowledge, and smart systems in educational administration and leadership. IGI Global, 2020. p. 142-160.

LIBÂNEO, José Carlos. Educação escolar: Políticas, estrutura e organização. 4. ed. São Paulo: Cortez, 2007.

LLARENA, Rosilene Agapito da Silva; DUARTE, Emeide Nóbrega; SANTOS, Raquel do Rosário. Gestão do Conhecimento e desafios educacionais contemporâneos. Em Questão, Porto Alegre, v. 21, n. 2, p. 222-242, 2015.

MILES, Matthew; HUBERMAN, A. Michael; SALDAÑA, Johnny. Qualitative data analysis: a methods sourcebook. New York: Arizona State University, 2014.

NONAKA Ikujiro; TAKEUCHI, Hirotaka. Gestão do Conhecimento. Porto Alegre: Bookman, 2008.

NORO, Daniel Arruda; SILVA, Caroline Guterres; GUBIANI, Juçara Salete; LOPES, Luis Felipe. Comunidades de prática: Um modelo para a GC com base em um portal web. In: INTERNATIONAL SYMPOSIUM ON TECHNOLOGICAL INNOVATION, 8., 2016, Aracajú. Anais... Aracajú, 2016. p. 477-485.

NUNES, Ana Ignez Belem Lima; SILVEIRA, Rosemary do Nascimento. Psicologia da aprendizagem: Processos, teorias e contextos. Brasília, DF: Liberlivro, 2009. 
PINTO, Danieli; GARCIA, Karoline; TENÓRIO, Nelson. Technological communication tools in use - the shape of knowledge shared within software development teams. In: LIU, Hanxiao; BERNARDINO, Jorge; SALGADO, Ana Cristina; FILIPE, Joaquim (Eds). IC3K 2017. Proceedings of the 9th International Joint Conference on Knowledge Discovery, Knowledge Engineering and Knowledge Management, Funchal, Madeira, Portugal. Setúbal, Portugal: SCITEPRESS, 2017. p. 158-166.

PLESSIS, Marina Du. The strategic drivers and objectives of communities of practice as vehicles for knowledge management in small and medium enterprises. International Journal of Information Management, v. 28, p. 61-67, 2008.

RATAN, Agrawal Shiv; DIVYA, Mittal. Constructive usage of WhatsApp in education sector for strengthening relations. International Journal of Educational Management, v. 33, n. 5, p. 954-964, 1 Jan. 2019.

SAEED, Sadeghi Boroujerdi; KAVEH, Hasani; VAHID, Delshab. Investigating the influence of knowledge management on organizational innovation in higher educational institutions. Kybernetes, vol. 49, no. 2, p. 442-459, 1 Jan. 2019.

SALDAÑA, Johnny. The coding manual for qualitative researchers. London: Sage, 2015.

SANTOS, Cintia Almeida da Silva. Modelo de GC para organizações de educação profissional e tecnológica: A comunidade de prática na implementação de um repositório digital institucional. 2018. 271 f. Tese (Doutorado em Ciência, Tecnologia e Sociedade) Universidade Federal de São Carlos, São Carlos, 2018.

SARTORI, Ademilde Silveira; ROESLER, Jucimara. Comunidades virtuais de aprendizagem: Espaços de desenvolvimento de socialidades, comunicação e cultura. In: SIMPÓSIO: EAGOR@, PROFESSOR? PARA ONDE VAMOS?, 2., 2003. São Paulo. Anais.... São Paulo: COGEAE, 2003. p. 1-12.

SARTORI, Viviane. Comunidade de prática virtual como ferramenta de compartilhamento de conhecimento na educação a distância. 2012. 145 f. Dissertação (Mestrado em Engenharia e GC) - Universidade Federal de Santa Catarina, Florianópolis, 2012.

SENGE, Peter M.; MACCABE, Nelda C.; LUCAS, Timothy. Escolas que aprendem. Porto Alegre. Artmed, 2005.

SILVA, Adelson de Paula; SARTORI, Viviane. Comunidade de Prática virtual: ferramenta para gestão do conhecimento nos habitats de inovação. In: MENEGASSI, Cláudia Herrero Martins; BORTOLOZZI, Flávio; TENÓRIO, Nelson; SARTORI, Rejane. Gestão do conhecimento nas organizações: inovação, gestão, educação e tecnologia. Jundiaí: Paco Editorial, 2016. v. 2. p. 155-173. 
TENÓRIO, Nelson; PINTO, Danieli; BJØRN, Pernille. Accountability in Brazilian Governmental Software Project: How Chat Technology enables Social Translucence in Bug Report Activities. Computer Supported Cooperative Work (CSCW). The Journal of Collaborative Computing and Work Practices, v. 27, p. 715-740, 2017.

TENÓRIO, Nelson; BJØRN, Pernille. Online Harassment in the Workplace: the Role of Technology in Labour Law Disputes. Computer Supported Cooperative Work (CSCW), May 2019a.

. How a geographically distributed software team managed to negotiate successfully using chat technology. Revista Tecnologia e Sociedade, vol. 15, no. 37, 2 Jul. 2019b.

TONET, Helena Correa; PAZ, Maria das Graças Torres. Um modelo para o compartilhamento de conhecimento no trabalho. Rev. adm. contem., Rio de Janeiro, v. 10, n. 2, p. 75-94, 2006.

VIEIRA, Naldeir dos Santos. O papel das comunidades de prática na aprendizagem organizacional. In: SIMPÓSIO DE EXCELÊNCIA EM GESTÃO E TECNOLOGIA, 3., 2006, Rio de Janeiro. Anais... Rio de Janeiro: AEDB, 2006.

WAGNER, Ina. Women's voice: The case of nursing information systems. Al \& Society, v. 7, n. 4, p. 295-310, Dec. 1993.

WENGER, Étienne. Communities of practice: learning, meaning, and identity. Cambridge, New York: Cambridge University Press, 1998.

WENGER, Étienne. Knowledge management as a doughnut: shaping your knowledge strategy through communities of practice. Ivey Business Journal, v. 68, n. 3, Jan./Feb. 2004.

WENGER, Étienne. Communities of practice: Learning as a social system. Systems Thinker, v.9, n. 5, p. 2-3, 2008.

WENGER, Etienne. Communities of practice and social learning systems: the career of a concept. In: Social learning systems and communities of practice. London: Springer, 2010. p. 179-198.

(C) ETD- Educação Temática Digital Campinas, SP v.23 n.4 p.1002-1021 out./dez. 2021 
WIIG, Karl M. Knowledge management foundations: thinking about thinking. How people and organizations create, represent and use knowledge. Arlington, TX: Schema, 2002.

YIN, Robert K. Estudo de caso: planejamento e métodos. 4. ed. Porto Alegre: Bookman, 2010.

Revisão gramatical realizada por: Natália Nakano

E-mail: natinakano@gmail.com 